DOI 10.37882/2500-3682.2020.11.19

\title{
ИДЕИ И ПРЕДСТАВИТЕЛИ РУССКОГО МИРА: ФЕДОР ИВАНОВИЧ ТЮТЧЕВ
}

\section{IDEAS AND REPRESENTATIVES OF THE RUSSIAN WORLD: FYODOR IVANOVICH TYUTCHEV}

\section{E. Mochalov}

Summary: The article attempts to identify and systematically investigate the historiosophical views of one of the most prominent poets of the XIX century - Fyodor Ivanovich Tyutchev. Considering the epistolary heritage of the poet, his journalism, the author of the article came to the conclusion that Tyutchev can rightly be attributed to one of the first ideologists, creators of the concept of the Russian world. The article focuses on the analysis of Tyutchev's understanding of the role of the Russian Orthodox Church in Russia and in Europe, and Russia's place in world civilizational processes. The relevance of Tyutchev's judgments for modern Russia is particularly noted.

A significant place in the article is given to the consideration of Tyutchev's place in the context of Slavophilism. In addition, the role and significance of the epistolary heritage in the poet's work are substantiated. The article contains an analysis of a number of significant assessments of Tyutchev made by authoritative historians of Russian philosophy. among them are Mikhail Maslin and Anjey Valitsky.

Keywords: Russian world, Orthodoxy, Russia, civilization, West, Church, Europe, Slavs, revolution.
И мя Федора Ивановича Тютчева (1803-1873), одного из самых известных русских поэтов, знакомо, вероятно, каждому, кто интересуется историей русской литературы. Исследователи и почитатели Тютчева, в числе которых был один из самых известных философов Николай Александрович Бердяев, не без оснований подчеркивал удивительные образы природы и «ночную стихию» его стихов. Вместе с тем, творчество и наследие Тютчева настолько многогранно и интересно, что их осмысление позволяет сделать вывод о том, что дипломат, общественный деятель Федор Иванович Тютчев принадлежит к одним из идеологов Русского мира, стоит у истоков становления этой концепции.

Обратимся к наиболее значимым вехам биографии. Поэт родился в селе Овстуг Орловской губернии Брянского уезда, в старинной дворянской семье. Еще в детстве подросток обнаружил удивительные способности: прилежно учился, преуспел в домашнем дворянском воспитании.

В 1818 году Тютчев поступает в Московский универ-

\author{
Мочалов Евгений Владимирович \\ д.ф.н., профрессор, ФГБОУ ВО «Мордовский \\ государственный университет» \\ mochalov_ev@mail.ru
}

Аннотация: В статье предпринята попытка выявить и системно исследовать историософские взгляды одного из виднейших поэтов XIX века - Федора Ивановича Тютчева. Рассматривая эпистолярное наследие поэта, его публицистику, автор статьи пришел к выводу, что Тютчева по праву можно отнести к одному их первых идеологов, создателей концепции Русского мира. Большое место в статье уделено анализу осмысления Тютчевым роли Русской Православной Церкви в России и в Европе, места России в мировых цивилизационных процессах. Особо отмечается актуальность суждений Тютчева для современной России. Весомое место в статье уделено рассмотрению места Тютчева в контексте славянофильства. Кроме того, обоснованы роль и значение эпистолярного наследия в творчестве поэта. Статья содержит анализ ряда значимых оценок Тютчева, высказанных авторитетными историками русской философии. среди которых Михаил Маслин и Анжей Валицкий.

Ключевые слова: Русский мир, православие, Россия, цивилизация, Запад, церковь, Европа, славянство, революция.

ситет, где и знакомится со многими ставшими впоследствии знаменитыми современниками, в числе которых были Николай Погодин и Василий Жуковский. Поэту не было еще 18 лет, а он уже сдал на «отлично» государственный экзамен. Получив кандидатскую степень, выпускник в 1822 году отправляется в Петербург, поступает на службу в Государственную коллегию иностранных дел. С этого времени начинается дипломатическая карьера Тютчева в Европе: Германия, Мюнхен.

Тютчев вспоминает, что дипломатический корпус в Мюнхене был многочисленный, а баварская династия Виттельсбахов всячески старалась подчеркнуть свою значимость. В 1825 году Тютчев на короткое время возвращается в Россию, в 1826 году женится в Мюнхене на графине Ботмер и снова посещает Петербург с целью знакомства с своей жены родственниками.

Затем он направляется секретарем посольства в Турин, хотя надеется получить место в Вене; далее снова следует в Мюнхен. После смерти жены в 1839 году Тютчев остается в этом городе до 1843 года и только в 1844 
году уже окончательно возвращается в Россию, в Петербург, изредка совершая путешествия за границу. В 1848 году Тютчев занимает должность старшего цензора при Особой канцелярии Министерства иностранных дел. В этом же году, или, как полагают исследователи его творчества, в 1849 году опубликована статья «Россия и Европа», первоначально на французском языке, а в русском переводе в журнале «Русский архив» 1873 года.

Обратим внимание на то обстоятельство, что, находясь за границей, Тютчев оказался, собственно говоря, в эпицентре западноевропейской науки. Он внимательно изучает немецкую философию, поддерживает знакомство с самим Фридрихом Шеллингом, часто споря и полемизируя с ним по поводу способов истолкования догматов христианской веры.

Безусловно, эпоха, в которой жил и творил Федор Иванович - это время славянофильства. Вот как оценивал значение славянофилов Иван Сергеевич Аксаков, который составил первую биографию Федора Ивановича: они являются поклонниками «исторического и духовного призвания» России как представительницы православного Востока и славянского племени, предвещают ей великое будущее. Однако славянофилы никогда не пользовались большим успехом в русском обществе и стояли как бы особняком на дорогах исторической жизни России. ... Русская мысль трезвеет и крепнет в строгой школе приемов немецкого мышления и также пытается стать в сознательное, философское отношение к русской народности. С одной стороны, вырабатывается целая стройная доктрина, как продукт высших просвещенных соображений, - что спасение для России заключается в полнейшем отречении от всех народных, исторических, бытовых, религиозных преданий; во главе этого направления стоит Чаадаев. С другой, - сначала одиноко и большею частью еще в стихах, раздается протест Хомякова; к нему примыкает постепенно целая дружина молодых людей - из последователей Гегелевой философии, а потом и несколько самостоятельных мыслителей, как Киреевский и другие. Общество распадается на два стана: «западников» и «восточников»; за последними утверждается прозвище «славянофилов», данное им в насмешку петербургскою журналистикою». Вот атмосфера той эпохи, в которой суждено было прожить большую часть жизни Федору Ивановичу Тютчеву [3; с. 443-444].

Философское наследие Тютчева представлено прежде всего не только в стихах, но и в публицистике, в обширной переписке, в знаменитых статьях «Россия и Европа», «Римский вопрос», «Россия и Запад».

В эпистолярном жанре письма, адресованном Густаву Кольбу, редактору «Всеобщей газеты», Тютчев пишет, что Россия « ... в наши дни стала предметом жгучего бес- покойного любопытства ...», и полагает, что это вполне оправданно, так как «современная мысль, дитя Запада», видит в России если и не враждебную, то совсем чуждую и не зависящую от нее стихию». Поэт ставит своей задачей определить: что такое Россия? Каков смысл ее пребывания в мире, в чем ее исторический закон? Откуда пришла она? Куда идет? Что представляет собою? Вместе с тем, по мнению Тютчева «... философия истории еще не соблаговолила найти для нее место» [3; с. 32-33]. Поэт упрекает Запад, что он не открыл России. Даже зная, что за границами Запада существует Россия, европейские политики не относятся к ней, как к «законной сестре христианского Запада». «Но чтобы за этими пределами жила другая, Восточная Европа, вполне законная сестра христианского Запада, христианская, как и он, правда не феодальная и не иерархическая, однако тем самым внутренне более глубоко христианская; чтобы существовал там целый Мир, Единый в своем Начале, прочно взаимосвязанный в своих частях, живущий своей собственной «органической самобытной жизнью», - вот что невозможно допустить ....

В статье «Россия и Германия», опубликованной в 1844 году, Тютчев продолжает развивать направления историософской доктрины, уже изложенной им в письме к доктору Кольбу. Из процитированного выше отрывка следует вывод: поэт противопоставляет Западной Европе Европу Восточную, Россию, называя ее «целым Миром, Единым в своем духовном начале, более христианским, чем сам Запад».

Тютчев в высшей степени критично оценивает книгу маркиза де Кюстина о России, которая, как он полагает, является «свидетельством умственного бесстыдства и духовного разложения». «Истинный защитник России - История, «которая за три века разрешала все тяжбы, все критические отзывы о России в ее пользу». Тютчев не приемлет западноевропейской трактовки России, ее места и роли в мировой цивилизации, остроумно замечая, что очень много «зрелых умов» опускается до младенчески простодушного слабоумия, чтобы доставить себе удовольствие видеть в России какого-то людоеда XIX века» [3; с. 30].

Подлинным патриотизмом наполнено содержание «Записки» Тютчева: «Россия занимает огромное место в мире ... и представляет собой не только материальную силу». Он прямо утверждает, что «... Россия - это мир, только начинающий осознавать основополагающее начало собственного бытия» [3; с. 30]. Именно это осознание дает основание России занять свое собственное место в мировой цивилизации. Поэт убежден, что отличие между Россией и Западной Европой заключено только в том, что «нас называли Восточной Империей, Восточной Церковью», в которой верховная власть «не принадлежит внешнему авторитету, но упорядочивается, сдержи- 
вается и освящается христианством [3; с. 42].

Не может не вызывать одобрения мысль Тютчева, что самое главное для России - это «обрести веру в самих себя; осмелиться признать перед самими собой огромное значение наших судеб и целиком воспринять ... эту веру» [3; с. 51].

Задача же правительства России заключается как раз в соединении усилий лучших представителей общества, направленных на службу России.

В письме к А.И. Георгиевскому от 3 июля 1866 года Тютчев высказывает, на наш взгляд, исключительно плодотворное, на наш взгляд, в историческом плане суждение, что если произойдет объединение России со славянскими народами, то Россия будет представительницей «всего Славянского мира», вступит окончательно в свои исторические права, именно этим она осуществит свое «историческое призвание».

Отношениям России и Запада Тютчев также уделяет самое пристальное внимание. Главный враг России, по мнению Тютчева, - это революция. В этом отношении «восточный вопрос» в том виде, в каком он предстает современникам Тютчева, можно сформулировать в виде триады: Православная церковь, славянство, Россия. По мнению Тютчева, Россия готова уважать историческую законность и Запада, и его народов в единстве и в силе. Однако, не следует «... признавать за Европой право определять для России, какое место ей принадлежит на Востоке» [3; с. 313].

Современное общество и современная мысль, по мнению поэта, не всегда способны противостоять революции, ее следствиям, к которым относятся социализм, коммунизм и атеизм. Мыслитель исходит из того, что западная цивилизация совершенно не знакома с Россией. Он сравнивает западных ученых, которые пишут о России, с китайцами, которые судят о Европе, или с греками, которые судят о Риме, но в принципе ничего не знают о предмете суждения. Запад, по его мнению, видит в России только «материальный факт, материальную силу». Россия для него - это «следствие без причины», и философы Запада в своих трактатах в принципе уже зачеркнули целую половину европейского мира, к которому и принадлежит Россия.

Тютчев постулирует мысль, что основное понятие, в оценке которого расходятся русские и западноевропейские мыслители, кроется в цивилизации. Почему? Потому что у России свой собственный путь, а безумное, «мирное» подражание Европе - это путь в никуда. Если даже Европа относится очень враждебно к России, то не следует огорчаться по этому поводу - наоборот, по мнению Тютчева, это «величайшая услуга», которую она нам оказывает. Он справедливо упрекает правительство России в том, что оно не увидело в Западе «своего естественного и необходимого противника, но старалось только служить ему подкладкой» [3; с. 222].

Противостояние России и Запада Тютчев оценивает как «вечный антагонизм». Русское правительство извратило инстинкты и притупило рассудок русского общества. Причем, это относится не ко всему русскому обществу, а только к его части, которую поэт метко называет словом «накипь» [3; с. 246].

Анализируя события истории, Тютчев утверждает, что все решающие битвы, решающие противостояния между Россией и Западом еще впереди. Если до этого все «авангардные дела были проиграны, то от исхода предстоящий борьбы зависит будущее страны: «...которая из двух самостоятельностей должна погибнуть: наша или Западная; но одна из них должна погибнуть непременно - быть иль не быть, мы или они... Теперь если мы взглянем на себя, на Россию, что мы видим? ... Сознание своего единственного исторического значения ею совершенно утрачено, по крайней мере, в так называемой образованной, правительственной России. Живет ли оно еще в народе, одному Богу известно» [3; с. 256].

Современное правительство способствует «разрыву со страной, с ее историческим прошлым». Оно не признает никакого иного права, кроме того, которое исходит от «материальной силы самой власти, но никак не от Бога».

Поэт в письме к А.Д. Блудовой от 28 сентября 1857 года восклицает: «Переберите одного за другим всех наших государственных и правительственных деятелей, прислушайтесь к их словам, вникните в самую суть их убеждений, и вы найдете, за одним или двумя исключениями, что у всех, даже у лучших, по-видимому, нет иного credo, о котором я только что сказал... Одним словом, власть в России на деле безбожна, ибо неминуемо становишься безбожным, если не признаешь существование живого непреложного закона, стоящего выше мнимого права, которое по большей части есть ничто иное, как скрытый произвол» [3; с. 256].

Именно это состояние и стало причиной нравственного бессилия «в правительстве, при всей его благонамеренности», которое характеризуется Тютчевым, как «бессмущающаяся пошлость» [3; с. 269].

Может быть впервые в истории отечественной социальной философии Тютчев рассуждает о России, о Русском мире в тесной связи с Русской Православной Церковью, Православием. Тютчев видит в православном Востоке «огромный мир, который возвышен греческим крестом, и этот огромный мир - он един в своем нача- 
ле. Он очень тесно связан со всеми своими частями, он живет своей собственной жизнью, самобытной и неразрушимой» [3; с. 45]. Даже если он физически может быть разделен, то нравственно он все равно будет «единым и неделимым» [Там же]. Косвенным доказательством такого суждения является поговорка: «все Бог создал и устроил хорошо, кроме двух вещей, а именно - Папы и Турка» [Там же] .

Тютчев оценивает Церковь в России не только как национальную в обычном значении этого слова, а главную форму, выражающую народность целого мира. И она, эта «Церковь, Восточная Церковь, Православная Церковь» становится как бы «синонимом России» [3; с. 47]. Русская Православная Церковь, Восточная церковь настолько и едина с судьбой России, что, по мнению Тютчева, вполне закономерен вывод: «...где существует православная Церковь, там в самых разных областях жизни обнаруживается и присутствие России» [Там же]. Таким образом, трактовка Тютчевым роли и значения России в современном мире связывается им вполне закономерно с историческими судьбами русского Православия.

Тютчев отрицательно оценивает западное христианство, полагая, что оно пытается постоянно устранить влияние Православия на Востоке, и когда не удалось это сделать, то католичество стремится подорвать значение восточной церкви «философской проповедью». Итог такого рода дискуссий однозначен: «Восточная Церковь есть православная Империя, Восточная Церковь есть законная наследница вселенской Церкви, православная Империя едина в своем основании, тесно связана во всех своих частях».

Естественно, что врага церкви и общества Тютчев видит в революции, как порождении Запада. В статье «Россия и революция» он пишет: «... Россия - христианская держава, русский народ является христианским не только потому, что вера его глубоко укоренена в его духе, - он является таковым благодаря способности к самоотречению и самопожертвованию» что и составляет его нравственную основу. Революция, выступая врагом христианства на первый план выдвигает человеческое «я» и не признает, и не принимает никакого другого закона, кроме как своего собственного. Революция приберегает только для себя «дух смирения и самоотвержения», но на деле она стремится заменить гордостью и превозношением «дух смирения и самоотвержения», а вместо милосердия поставить благотворительность, вместо «братства во Христе она пытается установить братство, навязанное страхом перед господином народом [3; с. 54].

На наш взгляд, очень актуально звучит призыв Тютчева, что мы, наша цивилизация, не должны и не можем признавать за Европой право определять для России, какое место ей надлежит занять на Востоке? [3; с. 313]. Он весьма критически относится к власти, в которой отсутствуют принципы и нравственные убеждения, которая основана только на «мерах материального угнетения», выступает пособником «революционного ниспровержения». Характеризуя современное ему русское общество, Тютчев оценивает его как «одно из самых бесцветных, самых заурядных в умственном и нравственном отношении среди тех, что когда-либо появлялись на мировой арене» [3; с. 407]. Свидетельство тому равнодушие, которое было проявлено к событиям в самом сердце Православия, Константинополе, что низводит русское общество до уровня «римского католицизма» и «превращает религию в орудие стремления к политическому господству» [Там же].

Пронзительно звучат слова Тютчева о том, что сам «Господь начертал огненными стрелами предназначение России» [3; с. 62], потому что Запад «уходит со сцены, все рушится и гибнет во всеобщем мировом пожаре». Это не могут предотвратить и в этом отношении римский «Католицизм и Протестантизм», и только папство - это «столп, который подпирает Запад, его здание, которое уцелело среди этих перипетий». И вот здесь-то, по мнению Тютчева и наступает «промыслительная» логика, которая управляет внутренними законами мира.

Реформация XVI века нанесла большой ущерб римской католической церкви, поэтому западноевропейская цивилизация, в отличие от России, очень уязвима к революции, которая в своем отношении к христианству формулирует главный лозунг: «Государство не имеет религии». Государство запрещает государственные религии, по мнению Тютчева только потому, что имеет свою собственную, которая как раз и есть революция.

Доказывая выдвинутый в статье тезис о Тютчеве как идеологе Русского мира, мы уже привели целый ряд его высказываний, содержащих призывы к славянам объединиться вокруг России. В своих сочинениях Тютчев четко обосновывает ту цивилизационную роль, которую суждено играть России. В письме к одному из идеологов славянофильства Юрию Федоровичу Самарину от 15 мая 1867 года он пишет: «Все зависит от того, как славяне понимают и чувствуют свои отношения к России. В самом деле, если они - а к этому весьма склонны некоторые из них, - если они видят в России лишь силу - дружескую, союзную, вспомогательную, но, так сказать, внешнюю, то ничего не сделано и мы далеки от цели. А цель эта будет достигнута лишь тогда, когда они искренно поймут, что составляют одно с Россией, когда почувствуют, что связаны с нею той зависимостью, той органической общностью, которые соединяют между собой все составные части единого целого, действительно живого... Через сколько бедствий, вероятно, придется им пройти прежде, чем они примут эту точку зрения целиком, со всеми ее последствиями. Однако и в настоящее время ясное и точное провозглашение этой истины в виде философской формулы было бы, по- 
моему, весьма кстати ...» [3; с. 327-328].

Небезынтересно, что историософские взгляды Федора Ивановича Тютчева были облечены и в стихотворную форму. Например, замечательно стихотворение, адресованное чешскому просветителю Вацлаву Ганке. «Вековать ли нам в разлуке, не пора ль очнуться нам и простерть друг другу руки, к нашим кровным и друзьям? ... О, какими вдруг лучами озарились все края! Обличилась перед нами вся Славянская Земля!» [3; с. 157].

Совершенно очевидно, что в публицистике, эпистолярном и стихотворном наследии Федора Ивановича Тютчева находит свое глубокое выражение стремление к возвращению Православной Империи, к возвращению Константинополя, соединению двух церквей - Восточной и Западной. Косвенным доказательством тому служит стихотворение «Русская география»: «Москва и Град Петров, и Константинов Град - вот царства русского заветные столицы... Но где предел ему? и где его границы на север, на восток, на юг и на закат? Грядущим временам судьбы их обличат...» [3; с. 160].

Едва ли есть основания принимать не критически оценку взглядов Тютчева, которая была дана таким маститым, к сожалению недавно ушедшим от нас, польским историком русской философии Анджеем Валицким: « Решительная победа Запада в «восточном вопросе» лишала смысла работу по созданию мифа о России как о новом воплощении Империи Востока. Тютчев смирился с такой минимализацией идеалов и свел свою теократическиимперскую картину к конвенциональному панславизму, который был свойствен эпигонам славянофильства» [1].

Оставив в стороне национальный контекст работы Валицкого, поясним свою позицию. Прежде всего отметим, что поэта, по нашему мнению, нельзя отнести к простым «эпигонам славянофильства». Мысли, высказанные Тютчевым, оригинальны и глубоки благодаря своей устремленности в сферу реальной политики. Поэт, дипломат, философ. Эти три ипостаси невозможно разделить при оценке мировоззрения Федора Ивановича, И, наконец, нельзя не сказать о нравственно-религиозном измерении его историософии, которое соединяет в себе не только мечтания об идеале, но и критический, объективный взгляд на российскую действительность середины XIX века.

Дополнительным аргументом в пользу позиции автора статьи может служить следующая оценка славянофилов: «Славянофильство не представляло собой ни политическую партию, ни оформленную теоретическую школу. Оригинально мыслившие философы-славянофилы отнюдь не стремились выработать какую-либо общую «платформу» или согласованную политическую идеологию. Общего согласия не удавалось достичь даже по таким важным вопросам, как социальный идеал и пути его достижения» [2; с. 133].

Именно эти обстоятельства дают, на наш взгляд, весомые основания отнести поэта к плеяде оригинальных идеологов концепции Русского мира.

Завершая критический обзор творчества Федора Ивановича Тютчева, приведем высказывание Бориса Тарасова: «Историософские размышления Тютчева, позволяющие обнаруживать подводные течения и соразмерно оценивать видимый «ход ужасной реальности жизни», весьма актуальны для осознания губительных закономерностей нашего времени» [3; с. 24].

И последнее. Оценивая значение этого выдающегося деятеля культуры XIX века в истории русской социальной философии, трудно не согласиться с высказыванием Ивана Сергеевича Аксакова: «Федор Иванович Тютчев не деятель в общепринятом смысле этого слова, он просто явление; явление общественное и личное, в высшей степени замечательное и любопытное для изучения. Его деятельность почти непосредственно сливается с самим его бытием» [3; с. 413].

\section{ЛИТЕРАТУРА}

1. Валицкий А. Россия, католичество и польский вопрос / пер., послесл. Твердисловой Е.С. - М: Изд-во Московского университета, 2012. - 624 с.

2. История русской философии: учебник / под. ред. М.А. Маслина. - изд.2-е. - М.: КДУ, 2008. - 638 с.

3. Тютчев Ф.И. Россия и Запад. Сост.. вступ. статья, перевод и коммент. Б.Н. Тарасова. - М.: Культурная революция. Республика, 2007. - 574 с.

(с) Мочалов Евгений Владимирович (mochalov_ev@mail.ru). 